\title{
Relationship between concentrations of cortisol in ovarian follicular fluid and various biochemical markers of follicular differentiation in cyclic and anovulatory cattle
}

\author{
L. J. Spicer† and S. A. Zinn \\ Department of Animal Science, Michigan State University, East Lansing, Michigan 48824, U.S.A.
}

\begin{abstract}
Summary. Concentrations of cortisol were determined in pooled fluid of small $(<10 \mathrm{~mm})$ and large $(\geq 10 \mathrm{~mm})$ follicles of cyclic cattle (Exp. 1), and in fluid of the largest follicle of 17 post-partum anovulatory cows (Exp. 2). In Exp. 1, concentrations of cortisol in small follicles were greater $(P<0.05)$ than in large follicles $(14.7$ versus $13.2 \mathrm{ng} / \mathrm{ml}$ ), and varied significantly with stages of the cycle; small and large follicles had the highest cortisol concentration during the early luteal phase of the cycle. Large follicles had 2-fold greater concentrations of oestradiol than did small follicles, whereas small follicles had 2-fold greater concentrations of androstenedione than did large follicles. Across pools of follicular fluid, cortisol concentrations were correlated only to androstenedione concentrations $(r=0.65, P=0.07)$. In Exp. 2, concentrations of cortisol did not significantly differ between oestrogen-active (oestradiol $>$ progesterone in follicular fluid) and oestrogen-inactive (progesterone $>$ oestradiol) follicles, although oestrogen-active follicles had a 24 -fold greater concentration of oestradiol than did oestrogen-inactive follicles. Cortisol concentrations were correlated to hCG binding capacity of thecal cells $(r=-0.35, P=0.08)$ and to follicular diameter ( $r=0.45, P<0.05$ ). These results suggest that normally fluctuating concentrations of cortisol in follicular fluid of cattle play little or no active role in follicular differentiation in vivo.
\end{abstract}

\section{Introduction}

Exogenous glucocorticoids prolong the reproductive cycles of cattle (Kanchev et al., 1976; Stoebel \& Moberg, 1982) and rats (Smith et al., 1971; Ramaley, 1976). These inhibitory effects of exogenous glucocorticoids on reproductive function have been explained, in part, by direct glucocorticoid inhibition of $\mathrm{LH}$ secretion on the anterior pituitary gland ( $\mathrm{Li} \&$ Wagner, 1983; Padmanabhan et al., 1983; Suter \& Schwartz, 1985). However, evidence for a direct inhibitory effect of glucocorticoids on ovarian follicular function also exists. Hsueh \& Erickson (1978) reported that glucocorticoids inhibit $\mathrm{FSH}$-induced aromatase activity by $50 \%$ in rat granulosa cells in vitro. It has also been shown that glucocorticoids can inhibit the FSH-induced increase in LH receptors of rat granulosa cells (Schoonmaker \& Erickson, 1983) which is a critical step in the development of preovulatory follicles. Moreover, the presence of glucocorticoid receptors in homogenates of rat ovaries has been documented (Schreiber et al., 1982) and provides further support for direct effects of glucocorticoids on ovarian function. However, little direct evidence exists to support the notion that the fluctuating concentrations of glucocorticoids in peripheral blood during an oestrous cycle in rats $(200-500 \mathrm{ng}$ corticosterone/ml; Raps et al., 1971;

$\Varangle$ Present address and reprint requests: Department of Medicine, The Milton S. Hershey Medical Center, The Pennsylvania State University, Hershey, PA 17033, U.S.A. 
Buckingham et al., 1978) or cattle (3-15 ng cortisol/ml; Garverick et al., 1971; Swanson et al., 1972; Roussel et al., 1983) are involved in follicular differentiation in vivo.

Therefore, our objective was to determine whether concentrations of cortisol in follicular fluid were associated with concentrations of progesterone, androstenedione or oestradiol in follicular fluid or numbers of gonadotrophin receptors in the same follicles of cattle during an oestrous cycle or post-partum anoestrus.

\section{Materials and Methods}

Experiment 1. Approximately 100 pairs of ovaries were obtained from beef and dairy cows within 30 min of slaughter at a local abattoir, placed on ice, and stage of the oestrous cycle was estimated as previously described (Ireland $e t$ al., 1980). Based on gross morphology of the uteri and ovaries, all cows were $>20$ days post partum. Pairs of ovaries were separated into three groups: early luteal (Days 1-10), mid-luteal (Days 11-17), and late luteal (Days 18-20). Two to three follicles were removed from each pair of ovaries. Follicular fluid was aspirated from follicles classified as large ( $\geq 10 \mathrm{~mm}$ in diameter) or small $(5-<10 \mathrm{~mm}$ in diameter), pooled within each size and stage-of-cycle category, centrifuged to remove cellular debris, and frozen. Samples were stored at $-20^{\circ} \mathrm{C}$ until assayed in quadruplicate for progesterone, androstenedione and oestradiol (Ireland \& Roche, 1982) and cortisol (Purchas et al., 1985) concentrations. Cortisol binding globulin is destroyed in the procedure to measure cortisol in follicular fluid and so concentrations of cortisol reported are total cortisol. Respective intra- and inter-assay coefficients of variation were 12.9 and $20.3 \%$ for oestradiol, 7.2 and $11.2 \%$ for progesterone, 9.8 and $10.5 \%$ for androstenedione, and 2.2 and $13 \%$ for cortisol. Sensitivities of the oestradiol, progesterone, androstenedione and cortisol assays were $4 \cdot 0,40 \cdot 0,30 \cdot 0$ and $420 \mathrm{pg} /$ tube, respectively. Cross-reactivity of the cortisol antiserum with cortisone, corticosterone, progesterone, oestradiol-17 $\beta$ and testosterone were 16,3, $<1,<1$ and $<1 \%$, respectively (Purchas et al., 1985).

Experiment 2. Pairs of ovaries were obtained from 17 anovulatory beef cows that had suckled (average $23 \pm 2$ days after parturition) as previously described (Spicer et al., 1986b). All cows used in this experiment were anovulatory as determined by the absence of newly formed corpora lutea or concentrations of progesterone in serum of $<1 \mathrm{ng} / \mathrm{ml}$. The largest follicle from each pair of ovaries was removed, its diameter was determined with a vernier caliper and fluid was collected. Granulosa and thecal layers of each follicle were removed and separated via blunt dissection, placed in phosphate-buffered saline containing $20 \%$ glycerol $(\mathrm{v} / \mathrm{v})$, quickly frozen and stored at $-70^{\circ} \mathrm{C}$ until assayed for binding capacity of hCG (LH) and FSH as previously described (Spicer et al., 1986a). Briefly, numbers of hCG (LH) and FSH binding sites (expressed as d.p.m./ $\mu \mathrm{g}$ DNA) were determined by saturation analyses using radiolabelled hCG and ovine FSH from a single iodination. Respective intra- and inter-assay coefficients of variation were $5 \cdot 2$ and $14.6 \%$ for hCG, and 5.6 and $13.1 \%$ for oFSH. Sensitivities of the hCG and FSH radioreceptor assays were 88 and 109 d.p.m./ $\mu$ g DNA, respectively. Histological examination of the thecal preparations showed that contamination by granulosa cells was $<10 \%$. Follicular fluid samples were stored at $-20^{\circ} \mathrm{C}$ until assayed for progesterone, androstenedione, oestradiol and cortisol as described in Exp. 1.

Statistical analyses. For Exp. 1, a $2 \times 3$ factorial analysis of variance was conducted to test main effects of 'stage of cycle' and 'follicular size' with interactions on concentrations of follicular fluid steroids. For Exp. 2, individual follicles were categorized as oestrogen-active (oestradiol > progesterone in follicular fluid; Ireland \& Roche, 1982) or oestrogen-inactive (progesterone $>$ oestradiol in follicular fluid) and tested for significant differences in concentrations of steroids in follicular fluid and amount of specific binding of gonadotrophins to granulosa and thecal cells using Student's $t$ test. For all experiments, simple correlation coefficients were calculated between concentrations of cortisol and concentrations of the various follicular fluid steroids, and between concentrations of cortisol and gonadotrophin binding capacity of granulosa and thecal cells.

\section{Results}

\section{Experiment 1}

Concentrations of cortisol in follicular fluid varied $(P<0.01)$ with stage of the oestrous cycle such that concentrations in large and small follicles were greatest during the early luteal phase (Table 1). Small follicles, on average, had $11 \%$ greater concentrations of cortisol at all stages than did large follicles $(P<0 \cdot 05)$.

Concentrations of progesterone in large follicles were highest during the early luteal phase and lowest during mid-luteal phase of the oestrous cycle (Table 1). In contrast, concentrations of progesterone in small follicles were highest during the late luteal phase and lowest during the mid-luteal phase of the oestrous cycle. Small follicles had greater concentrations of progesterone 
Table 1. Concentrations of steroids in follicular fluid of large $(\geq 10 \mathrm{~mm})$ and small $(<10 \mathrm{~mm}$ ) follicles during three stages (early luteal, mid-luteal and late luteal) of the oestrous cycle of the cow

\begin{tabular}{|c|c|c|c|c|c|c|c|}
\hline \multirow{2}{*}{$\begin{array}{l}\text { Steroid } \\
(\mathrm{ng} / \mathrm{ml})\end{array}$} & \multicolumn{2}{|c|}{ Early luteal } & \multicolumn{2}{|c|}{ Mid-luteal } & \multicolumn{2}{|c|}{ Late luteal } & \multirow{2}{*}{$\begin{array}{c}\text { Pooled } \\
\text { s.e. }\end{array}$} \\
\hline & Large & Small & Large & Small & Large & Small & \\
\hline Cortisol $^{\mathrm{a}}$ & $13 \cdot 7$ & $15 \cdot 9$ & $12 \cdot 9$ & $14 \cdot 2$ & $13 \cdot 1$ & $14 \cdot 0$ & $0 \cdot 2$ \\
\hline Progesterone $^{\mathbf{a}, \mathbf{b}}$ & 280 & 260 & 195 & 251 & 240 & 283 & 10 \\
\hline Androstenedione $\mathrm{a}^{\mathrm{a}, \mathrm{b}}$ & 7.8 & $25 \cdot 4$ & 8.6 & $19 \cdot 6$ & $20 \cdot 0$ & 22.5 & $2 \cdot 3$ \\
\hline Oestradiol $^{\mathbf{a}, \mathbf{b}}$ & $68 \cdot 4$ & $66 \cdot 0$ & $79 \cdot 8$ & $34 \cdot 0$ & $90 \cdot 9$ & $46 \cdot 4$ & $4 \cdot 7$ \\
\hline
\end{tabular}

a Significant stage and size effect $(P<0 \cdot 01)$.

'Significant stage $\times$ size interaction $(P<0.01)$.

than did large follicles during the mid- and late luteal phase, whereas large follicles had greater concentrations of progesterone during the early luteal phase of the cycle (Table 1).

Concentrations of androstenedione in large follicles were highest during the late luteal phase and lowest during the early luteal phase (Table 1). In small follicles, concentrations of androstenedione did not significantly change with stage of the oestrous cycle (Table 1).

Concentrations of oestradiol were highest in large follicles during the late luteal phase and highest in small follicles during the early luteal phase of the oestrous cycle (Table 1). Concentrations of oestradiol were lowest during the early luteal phase in large follicles and lowest during the mid-luteal phase in small follicles.

Concentrations of cortisol in follicular fluid tended to correlate with concentrations of androstenedione in follicular fluid $(r=0.65, n=6, P=0.07)$ but not with concentrations of oestradiol $(r=-0 \cdot 38, P>0 \cdot 10)$ or progesterone $(r=0 \cdot 37, P>0 \cdot 10)$.

\section{Experiment 2}

Concentrations of cortisol in fluid of oestrogen-active and oestrogen-inactive follicles did not differ $(P>0 \cdot 10$; Table 2). Similarly, concentrations of androstenedione did not differ between active and inactive follicles (Table 2 ). In contrast, concentrations of oestradiol were 24-fold greater $(P<0.05)$ in active than inactive follicles, whereas concentrations of progesterone were 2 -fold greater $(P<0.05)$ in inactive than active follicles. Also, binding capacity of hCG $(\mathrm{LH})$ to thecal homogenates and granulosa cells was 2- to 3-fold greater in the active follicles. Binding capacity of FSH to granulosa cells $(535 \pm 74$ d.p.m./ $\mu$ g DNA) did not significantly differ between active and inactive follicles $(P>0 \cdot 10)$. Concentrations of cortisol in follicular fluid were not significantly $(P>0 \cdot 10)$ correlated to concentrations of progesterone $(r=0.01)$, oestradiol $(r=0 \cdot 19)$ or androstenedione $(r=0.12)$ in follicular fluid, or binding capacity of hCG $(r=0.06)$ and FSH $(r=-0 \cdot 19)$ to granulosa cells. In contrast, concentrations of cortisol tended to correlate to hCG (LH) binding capacity of thecal homogenates $(r=-0.35, n=17, P=0.08)$ and significantly correlate to follicular diameter $(r=0.45, P<0.05)$.

\section{Discussion}

Substantial evidence exists to support the notion that abnormally high levels of glucocorticoids in blood (exogenously supplied or stress-induced) are inhibitory to reproductive functions in cattle (Kanchev et al., 1976; Welsh \& Johnson, 1981; Stoebel \& Moberg, 1982; Echternkamp, 1984). However, no evidence existed previously to support the idea that normally fluctuating concentrations of glucocorticoids play a role in ovarian function in vivo in any species. 
Table 2. Comparisons among follicular fluid steroids and LH receptors in granulosa cells and thecal cells of the largest follicle in post-partum cattle of Exp. 2 categorized as oestrogen-active or oestrogen-inactive

\begin{tabular}{|c|c|c|c|c|c|c|c|c|c|}
\hline \multirow[b]{2}{*}{ Group } & \multirow[b]{2}{*}{$\begin{array}{l}\text { No. } \\
\text { of } \\
\text { cows }\end{array}$} & \multirow[b]{2}{*}{$\begin{array}{c}\text { Days } \\
\text { post } \\
\text { partum }\end{array}$} & \multirow{2}{*}{$\begin{array}{l}\text { Average } \\
\text { diam. } \\
\text { follicle } \\
(\mathrm{mm})\end{array}$} & \multicolumn{4}{|c|}{$\begin{array}{l}\text { Hormone conc. } \\
\text { ( } \mathrm{gg} / \mathrm{ml} \text { follicular fluid) }\end{array}$} & \multicolumn{2}{|c|}{$\begin{array}{l}\text { LH receptor conc. } \\
\text { (d.p.m./ } / \text { g DNA) }\end{array}$} \\
\hline & & & & Cortisol & $\begin{array}{l}\text { Proge- } \\
\text { sterone }\end{array}$ & $\begin{array}{l}\text { Andro- } \\
\text { stene- } \\
\text { dione }\end{array}$ & Oestradiol & $\begin{array}{l}\text { Thecal } \\
\text { cells }\end{array}$ & $\begin{array}{l}\text { Granulosa } \\
\text { cells }\end{array}$ \\
\hline $\begin{array}{l}\text { Active } \\
\text { Inactive } \\
\text { (range) }\end{array}$ & $\begin{array}{r}7 \\
10\end{array}$ & $\begin{array}{l}21 \pm 2 \\
24 \pm 2 \\
(14-30)\end{array}$ & $\begin{array}{l}11 \pm 1 \\
13 \pm 1 \\
(8 \cdot I-15 \cdot 4)\end{array}$ & $\begin{array}{c}19 \pm 1 \\
20 \pm 2 \\
(7-50)\end{array}$ & $\begin{array}{c}165 \pm 30^{*} \\
81 \pm 9 \\
(43-351)\end{array}$ & $\begin{array}{c}12 \pm 3 \\
11 \pm 4 \\
(1-38)\end{array}$ & $\begin{array}{c}12 \pm 6^{*} \\
286 \pm 57 \\
(1-606)\end{array}$ & $\begin{array}{l}210 \pm 22^{*} \\
572 \pm 173 \\
(109-1838)\end{array}$ & $\begin{array}{c}972 \pm 255^{*} \\
1818 \pm 256 \\
(383-2963)\end{array}$ \\
\hline
\end{tabular}

†Oestradiol concentration $>$ progesterone concentration in follicular fluid.

$\ddagger$ Progesterone concentration $>$ oestradiol concentration in follicular fluid.

Values are mean \pm s.e.m.

*Significantly different from value for inactive cows $(P<0 \cdot 05)$.

In the present study, the concentrations of cortisol in pooled fluid of small follicles from cyclic cows were greater than in large follicles. Since a cortisol binding globulin has been found in pig follicular fluid and its binding capacity decreases with increased follicular size (Mahajan \& Little, 1978; Mahajan et al., 1980), perhaps small follicles contain a greater concentration of cortisol binding globulin than do large follicles thereby sequestering serum-derived glucocorticoids. In vitro, high concentrations of glucocorticoids have been shown to inhibit FSH-induced aromatase activity and stimulate FSH-induced progesterone production in rat granulosa cells (Hsueh \& Erickson, 1978; Adashi et al., 1981; Schoonmaker \& Erickson, 1983). Thus, greater concentrations of cortisol and progesterone and lower concentrations of oestradiol in small than in large follicles are consistent with previous in-vitro studies. However, only the correlation between cortisol and androstenedione concentrations in follicular fluids approached significance in Exp. 1, suggesting that a relationship may exist between androstenedione and cortisol (and/or cortisol-binding globulin) in cyclic cattle. Effects of glucocorticoids on follicular cell androgen production have not been evaluated in vitro. In contrast, no significant correlation existed between concentrations of cortisol and androstenedione in Exp. 2. Since concentrations of androstenedione decrease with an increase in follicular size both in cyclic and post-partum cattle (Ireland \& Roche, 1982; Spicer et al., 1986a), the difference between Exps 1 and 2 with regard to concentrations of cortisol and androstenedione in follicular fluid may be due, in part, to the fact that only large (average $11-13 \mathrm{~mm}$ ) follicles were collected in Exp. 2. In addition, only total cortisol was measured in follicular fluid in the present study. Since unbound cortisol may be more physiologically relevant, further studies are needed to determine whether glucocorticoids affect thecal/granulosa cell androgen production, and to determine the relationship between cortisol-binding globulin and follicular androgen production.

To evaluate more thoroughly the relationship between concentrations of cortisol in follicular fluid and steroidogenic capacity of individual follicles, the largest follicles from 17 post-partum cows were assessed for steroid concentrations and the number of gonadotrophin binding sites. Oestrogen-active follicles had several-fold greater concentrations of oestradiol and greater binding capacity of hCG (LH) than did oestrogen-inactive follicles. However, concentrations of cortisol in the two types of follicles did not differ. Glucocorticoids have been shown to inhibit FSH-induced increases in LH receptors of rat granulosa cells (Schoonmaker \& Erickson, 1983), but concentrations of cortisol in follicular fluid of cows in Exp. 2 were not significantly correlated to binding capacity of hCG $(\mathrm{LH})$ in granulosa cells. Since high concentrations of glucocorticoids ( $\geq 36 \mathrm{ng} / \mathrm{ml}$ ) were needed to inhibit FSH-induced increases in LH receptors in previous in-vitro studies (Schoonmaker \& Erickson, 1983), perhaps normally fluctuating levels of glucocorticoids in follicular fluid play no active role in follicular differentiation in vivo. This suggestion is supported by 
the fact that most $(>90 \%)$ serum glucocorticoids are bound to cortisol-binding globulin (Daughaday, 1967; Forest \& Pugeat, 1981). More likely, the evidence to date supports the concept that abnormally high levels of glucocorticoids, manifested only during periods of stress, suppress reproductive activity by directly inhibiting pituitary LH secretion (Li \& Wagner, 1983; Padmanabhan et al., 1983; Suter \& Schwartz, 1985) and/or ovarian oestradiol production (Hsueh \& Erickson, 1978; Adashi et al., 1981; Schoonmaker \& Erickson, 1983).

In the cyclic cattle of Exp. 1, concentrations of cortisol were significantly greater in small $(5-9.9 \mathrm{~mm})$ than large $(\geq 10 \mathrm{~mm})$ follicles. However, when evaluating the largest follicle of postpartum cattle in Exp. 2, there was a significant positive correlation between follicular size and cortisol concentrations. The reason for the difference between Exps 1 and 2 in regard to follicular size and cortisol concentrations is unclear but may be explained, in part, by the difference in size of follicles collected in the two experiments.

Collectively, the results of the present studies indicate that, in the face of dramatic changes (2-24-fold) in concentrations of oestradiol in follicular fluid, concentrations of cortisol in follicular fluid remain relatively stable $(12-20 \mathrm{ng} / \mathrm{ml})$. Since low concentrations of cortisol are present in the follicular fluid (present study) and high levels of cortisol are needed to elicit maximal responses to granulosa cells in vitro (Hsueh \& Erickson, 1978; Adashi et al., 1981), we suggest that normally fluctuating concentrations of cortisol in follicular fluid of cattle play no active role in differentiated functions of follicles in vivo.

We thank Steven Lyth and Kwan-yee Leung for technical assistance; the National Pituitary Agency, NIAMDD, U.S.A., for the hCG; Dr M. R. Sairam, Montreal, Quebec, Canada, for highly purified ovine FSH; Dr G. D. Niswender, Colorado State University, for the antiserum to androstenedione; Murco, Inc., Plainwell, Michigan, U.S.A., for donation of bovine ovaries; and Mrs Sandra Christian for excellent secretarial assistance. This work was supported in part by a grant from The Upjohn Company, Kalamazoo, Michigan, U.S.A.

\section{References}

Adashi, E.Y., Jones, P.B.C. \& Hsueh, A.J.W. (1981) Synergistic effect of glucocorticoids on the stimulation of progesterone production by folliclestimulating hormone in cultured rat granulosa cells. Endocrinology 109, 1888-1894.

Buckingham, J.C., Dohler, K.D. \& Wilson, C.A. (1978) Activity of the pituitary-adrenocortical system and thyroid gland during the oestrous cycle of the rat. $J$. Endocr. 78, 359-366.

Daughaday, W.H. (1967) The binding of corticosteroids by plasma protein. In The Adrenal Cortex, pp. 385-403. Ed. A. B. Eisenstein. Little Brown and Co., Boston.

Echternkamp, S.E. (1984) Relationship between LH and cortisol in acutely stressed beef cows. Theriogenology 22, 305-311.

Forest, M.G. \& Pugeat, M. (1981) Free and bound steroids in plasma: Methodology and physiopathological implications. In Physiological Peptides and New Trends in Radioimmunology, pp. 249-266. Ed. Ch. A. Bizollon. Elsevier/North-Holland, New York.

Garverick, H.A., Erb, R.E., Niswender, G.D. \& Callahan, C.J. (1971) Reproductive steroids in the bovine. III. Changes during the estrous cycle. J. Anim. Sci. 32, 946-956.
Hsueh, A.J.W. \& Erickson, G.F. (1978) Glucocorticoid inhibition of FSH-induced estrogen production in cultured rat granulosa cells. Steroids 32, 639-648.

Ireland, J.J. \& Roche, J.F. (1982) Development of antral follicles in cattle after prostaglandin-induced luteolysis: changes in serum hormones, steroids in follicular fluid, and gonadotrophin receptors. Endocrinology 111, 2077-2086.

Ireland, J.J., Murphee, R.L. \& Coulson, P.B. (1980) Accuracy of predicting stages of bovine estrous cycle by gross appearance of the corpus luteum. J. Dairy Sci. 63, 155-160.

Kanchev, L.N., Dobson, H., Ward, W.R. \& Fitzpatrick, R.J. (1976) Concentration of steroids in bovine peripheral plasma during the oestrous cycle and the effect of betamethasone treatment. J. Reprod. Fert. 48, 341-345.

Li, P.S. \& Wagner, W.C. (1983) In vivo and in vitro studies on the effect of adrenocorticotropic hormone or cortisol on the pituitary response to gonadotrophin releasing hormone. Biol. Reprod. 29, 25-37.

Mahajan, D.K. \& Little, A.B. (1978) Specific cortisol binding protein in porcine follicular fluid. Biol. Reprod. 18, 834-842.

Mahajan, D.K., Billiar, R.B. \& Little, A.B. (1980) 
Isolation of cortisol binding globulin (CBG) from porcine follicular fluid by affinity chromatography. $J$. Steroid Biochem. 13, 67-71.

Padmanabhan, V., Keech, C. \& Convey, E.M. (1983) Cortisol inhibits and adrenocorticotropin has no effect on luteinizing hormone-releasing hormone-induced release of luteinizing hormone from bovine pituitary cells in vitro. Endocrinology 112, 1782-1787.

Purchas, R.W., Zinn, S.A. \& Tucker, H.A. (1985) A simple method for separating unbound and bound cortisol in a radioimmunoassay. Analyt. Biochem. 149, 399-403.

Ramaley, J.A. (1976) Effect of corticosterone treatment on puberty in female rats. Proc. Soc. exp. Biol. Med. 153, 514-517.

Raps, D., Barthe, P.L. \& Desaulles, P.A. (1971) Plasma and adrenal corticosterone levels during the different phases of the sexual cycle in normal female rats. Experientia 27, 339-340.

Roussel, J.D., Clement, T.J., Aranas, T.J. \& Seybt, S.H. (1983) Changes in circulating plasma levels of cortisol in lactating and non-lactating dairy cattle during the estrous cycle. Theriogenology 19, 535-539.

Schoonmaker, J.N. \& Erickson, G.F. (1983) Glucocorticoid modulation of follicle-stimulating hormonemediated granulosa cell differentiation. Endocrinology 113, 1356-1363.

Schreiber, J.R., Nakamura, K. \& Erickson, G.F. (1982) Rat ovary glucocorticoid receptor: identification and characterization. Steroids 39, 569-584.

Smith, E.R., Johnson, J., Weick, R.F., Levine, S. \& Davidson, J.M. (1971) Inhibition of the reproductive system in immature rats by intracerebral implantation of cortisol. Neuroendocrinology 8, 94-106.
Spicer, L.J., Convey, E.M., Leung, K., Short, R.E. \& Tucker, H.A. (1986a) Anovulation in postpartum suckled beef cows. II. Associations among binding of ${ }^{125}$ I-labeled gonadotropins to granulosa and thecal cells, and concentrations of steroids in serum and various sized ovarian follicles. J. Anim. Sci. 62, $742-750$.

Spicer, L.J., Convey, E.M., Tucker, H.A. \& Echternkamp, S.E. (1986b) Effects of intermittent injections of LHRH on secretory patterns of LH and FSH and ovarian follicular growth during postpartum anovulation in suckled beef cows. J. Anim. Sci. 62, 1317-1323.

Stoebel, D.P. \& Moberg, G.P. (1982) Effects of adrenocorticotropin and cortisol on luteinizing hormone surge and estrous behavior of cows. J. Dairy Sci. 65, 1016-1024.

Suter, D.E. \& Schwartz, N.B. (1985) Effects of glucocorticoids on secretion of luteinizing hormone and follicle-stimulating hormone by female rat pituitary cells in vitro. Endocrinology 117, 849-854.

Swanson, L.V., Hafs, H.D. \& Morrow, D.A. (1972) Ovarian characteristics and serum LH, prolactin, progesterone, and glucocorticoid from first estrus to breeding size in holstein heifers. J. Anim. Sci. 34, 284-293.

Welsh, T.H., Jr \& Johnson, B.H. (1981) Stress-induced alterations in secretion of corticosteroids, progesterone, luteinizing hormone, and testosterone in bulls. Endocrinology 109, 185-190.

Received 4 February 1987 